\title{
Nutrition and Athlete Immune Health: New Perspectives on an Old Paradigm
}

\author{
Neil P. Walsh ${ }^{1}$ (D) \\ Published online: 6 November 2019 \\ (c) The Author(s) 2019
}

\begin{abstract}
Respiratory and gastrointestinal infections limit an athlete's availability to train and compete. To better understand how sick an athlete will become when they have an infection, a paradigm recently adopted from ecological immunology is presented that includes the concepts of immune resistance (the ability to destroy microbes) and immune tolerance (the ability to dampen defence yet control infection at a non-damaging level). This affords a new theoretical perspective on how nutrition may influence athlete immune health; paving the way for focused research efforts on tolerogenic nutritional supplements to reduce the infection burden in athletes. Looking through this new lens clarifies why nutritional supplements targeted at improving immune resistance in athletes show limited benefits: evidence supporting the old paradigm of immune suppression in athletes is lacking. Indeed, there is limited evidence that the dietary practices of athletes suppress immunity, e.g. low-energy availability and train- or sleep-low carbohydrate. It goes without saying, irrespective of the dietary preference (omnivorous, vegetarian), that athletes are recommended to follow a balanced diet to avoid a frank deficiency of a nutrient required for proper immune function. The new theoretical perspective provided sharpens the focus on tolerogenic nutritional supplements shown to reduce the infection burden in athletes, e.g. probiotics, vitamin C and vitamin D. Further research should demonstrate the benefits of candidate tolerogenic supplements to reduce infection in athletes; without blunting training adaptations and without side effects.
\end{abstract}

\section{Key Points}

A new paradigm for exercise immunology is presented that considers 'resistance' (the strength of the immune weaponry) and 'tolerance' (the ability to endure microbes and dampen defence activity).

A contemporary view is that immune 'resistance' is not suppressed in athletes under heavy training; as such, it is not surprising that nutritional supplements targeted towards improving immune 'resistance' show limited benefits to reduce the infection burden in athletes- 'if it ain't broke, don't fix it!'

This paradigm of 'resistance' and 'tolerance' helps to explain why nutritional supplements with tolerogenic effects (e.g. probiotics, vitamin C and vitamin D) are the new targets-tolerogenic supplements may reduce the infection burden in athletes.

Neil P. Walsh

N.Walsh@ljmu.ac.uk

1 College of Human Sciences, Bangor University, Bangor LL57 2PZ, UK

\section{Introduction}

"If we could give every individual the right amount of nourishment and exercise, not too little and not too much, we would have found the safest way to health."

Hippocrates c. $460-377$ B.C.

It has long been known that an individual's nutritional status influences both their susceptibility to infection and their response to infection in terms of clinical outcome [1, 2]. Leyton's seminal work in British and Russian prisoners during the Second World War made an important connection between malnutrition and tuberculosis morbidity; at a time predating vaccination for tuberculosis [1]. The emaciated prisoners shared the same living and working conditions, performing at least $12 \mathrm{~h}$ of hard manual labour each day on a daily diet providing only $\sim 1600 \mathrm{kcal}$. The British prisoners also received a Red Cross food supplement containing $1300 \mathrm{kcal}$ and $45 \mathrm{~g}$ protein each day. Despite the same exposure to infection, a comparative radiographic survey showed a tuberculosis prevalence of $1 \%$ in the British prisoners and $19 \%$ in the Russian prisoners: tuberculosis onset, development and death were more rapid in the malnourished Russian prisoners. Nutrient availability influences 
immunity because macro- and micro-nutrients are involved in a multitude of immune processes, e.g. macronutrients are involved in immune cell metabolism and protein synthesis and micronutrients in antioxidant defences. That there might be an important interaction between nutritional status and immune health in athletes under heavy training has received much interest and fervour amongst scientists and practitioners since Shephard and Shek's landmark review on this subject in 1995 [3].

Inadequate nutrition, specifically low energy availability, has been placed firmly in the spotlight recently as a risk factor for infection in elite athletes [4]. Approximately half of all female athletes in two recent studies were classified as having low energy availability and this was associated with a four to eight times higher risk of upper respiratory infection (URI) in the months preceding the summer Olympics $[4,5]$. Although these findings are limited to the level of association (not causation), they raise interest in the role that nutrition may play in maintaining athlete immune health, the focus of this review. The aim of this review is not to provide an exhaustive account of the influence of individual macronutrients and micronutrients on athlete immunity; this can be found elsewhere [6]. Rather, the aim is to provide a new theoretical perspective to improve our understanding of how nutrition may influence athlete immune health and set a path for more focused research efforts moving forward. The review covers important controversies, misunderstandings and paradoxes in the field. First up, to set the scene, recent advancements in our understanding of the infection burden in athletes and the prominent infection risk factors are covered. Upon this backdrop, the evidence that energy deficiency decreases immunity and increases infection in athletes is scrutinised. The overly simplistic and longstanding view held by many that nutritional supplements should be targeted towards countering the apparently weakened immune weaponry (termed 'resistance') in otherwise healthy elite athletes is also examined.

A new paradigm for exercise immunology, recently adopted in human immunology from ecological immunology [7], is offered that considers the beneficial tolerogenic interactions between pathogens and the immune system ('tolerance' refers to the ability to endure microbes). Looking through this new lens provides a much clearer picture with regard to the rather conflicting and often disappointing findings of studies investigating nutritional supplements and athlete immune health. This new theoretical perspective provides a framework for focused research endeavours on targeted tolerogenic nutritional supplements to reduce the burden of infection in elite athletes.

\section{Infections Pose a Serious Problem for Athletes}

An URI, such as a common cold, might only present an unwelcome nuisance for many of us; however, URI and other infections such as those that affect the gastrointestinal system may limit an elite athlete's availability to train and take part in major competition [8]. After injury, illness (primarily respiratory but also gastrointestinal) was the second most common reason for an elite athlete to seek medical attention either during training or when competing at the summer or winter Olympic Games [8-10]. In a 3-year surveillance study of 322 Olympic athletes, $~ 70 \%$ of illnesses recorded by medical staff resulted in 'time loss' (complete absence) from training and competition; the remaining illnesses resulted in 'performance restriction' (e.g. reduced volume and/or intensity of training) [8]. Needless to say, sickness absence from training is incompatible with success in elite sport, which demands a consistently high training volume. In accordance with this logic, the empirical evidence shows that medal winners at major sporting events, including the Olympics and World Championships, experience fewer URIs and shorter lasting URIs than less successful, national-level athletes [11, 12]. Furthermore, URI incidence correlates negatively with annual training volume in elite athletes, viz. 'the less sick, the more an athlete can train' [13].

Against their better judgement, athletes often choose to ignore illness symptoms for fear of missing training and competition [14]; likely they feel that achieving success is down to an ability to suffer and 'push on' through adversity, when others would stop. Runners who reported ongoing or recent illness symptoms (in the last 8-12 days) before an endurance race were more likely to drop out of the event; albeit, $~ 98 \%$ of runners did reach the finish line [14]. It is a widely held belief that heavy exertion may protract the course of an ongoing infection $[15,16]$. Worse still, heavy exertion during, or after incomplete recovery from, a viral infection can result in serious medical complications including myositis, rhabdomyolysis and myopericarditis; the latter of which can cause acute arrhythmias leading to sudden death $[17,18]$. Case reports in human casualties [17, 18], corroborated by the findings of animal research [19], indicate that a combination of heavy exertion and viral infection (particularly viruses that cause URI) increases the likelihood of life-threatening myopericarditis; likely either as a consequence of direct viral invasion of the heart or hostmediated inflammatory pathology [18]. A corollary of the host-mediated inflammation and immune perturbations during infection may be altered thermoregulation and an 
increased risk of life-threatening exertional heat stroke in military personnel and athletes [20]. Although limited to the level of association, case studies of exertional heat illness casualties often report recent infection symptoms [21]. Exertional heat illness is certainly not confined to military settings, or to lesser fit athletes, as half of all elite athletes in one recent survey reported having suffered heat illness symptoms (e.g. vomiting and collapse) and 1 in 12 reported a previous medical diagnosis of exertional heat illness [22]. Mindful of these risks, it cannot be overemphasised how important it is for athletes to wait until all symptoms have cleared before returning to exercise after infection, in line with current recommendations [23]. Clearly, respiratory and gastrointestinal infections pose a problem for high-level athletes; limiting availability for training and competition and in some cases leading to serious medical complications.

\subsection{Risk Factors for Infection and Lowered Immunity in Athletes}

Scholarly research on this topic began in earnest in the 1980s [24-27], thus it is somewhat surprising that only very recently has research begun to scratch the surface regarding the prominent risk factors for infection in elite athletes [4, $11,12]$. Central to the doctrine of early exercise immunology was the concept that heavy exercise temporarily decreases immunity providing an 'open window' for URI and other infections [25, 26]. Periods of overreaching and longer term mal-adaptation (coined 'overtraining') were also associated with neuroendocrine modulation, decreased immunity and increased URI [28, 29]. These findings supported the prevailing notion of the time that accumulated training stress compromised immune health and increased infection risk. As such, for many years 'exercise immunologists' broadly accepted, and focused their research efforts towards countering heavy exercise as a prominent risk factor for URI in athletes. Interested readers are directed elsewhere for comprehensive accounts of: the inner workings of the immune system [30]; the neuroendocrine modulation of immunity in response to stress [31]; and the influence of heavy exercise on immunity [32,33] and respiratory infection [34]. In short, both innate and acquired immunity are often observed to decrease transiently during the recovery period after prolonged heavy exertion; typically of the order 15-70\% [24, 35-39]. However, whether these transient changes in immunity with acute heavy exercise and intensified training are sufficient to increase URI susceptibility in accordance with the 'open window' theory has been in doubt for some time [13, 15, 39-41]. Ekblom et al.'s findings on URI at the 2000 Stockholm marathon provided the first serious challenge to the 'open window' theory by showing no increase in URI symptoms post-race [15]; contrasting earlier reports of increased URI after marathons and ultramarathons [27,
42]. In addition, Ekblom et al.'s observations supported the idea that pre-race URI symptoms may have accounted for reports of increased URI after endurance events [15].

Recent research highlights prominent risk factors for infection in elite athletes and military personnel broadly similar to those in the wider population; including, wintertime (common cold and influenza season) [11, 12]; high levels of psychological stress, anxiety and depression [5]; poor sleep ( $<6 \mathrm{~h}$ per night) [43] and long-haul travel [12]. By contrast, increases in training load resulted in relatively small increases in URI and gastrointestinal infection incidence in one recent study in elite swimmers [11] and no change in infection incidence in another recent study in elite cross-country skiers [12]. Psychological stress, sleep disturbances and physical exertion all influence immunity via activation of the hypothalamic-pituitary-adrenal axis and the sympathetic nervous-system. Common pathways and effector limbs for the body's response to stress in its various forms give rise to increases in circulating catecholamines and glucocorticoid hormones widely acknowledged to modulate immune function [31]. That poor mental health [5] and poor sleep [43] predict URI in elite athletes and military personnel is in keeping with seminal work, in the wider population, showing dose-response relationships between both psychological stress and the common cold [44] and sleep quantity and quality and the common cold [45] after intra-nasal inoculation with rhinovirus. Likewise, the increased incidence of URI and gastrointestinal infections after long-haul flights in elite athletes $[12,46]$ is a widely reported phenomenon in occupational travellers [47]. It is quite conceivable that aspects of psychological wellbeing (e.g. perceived stress and mood) account, at least in part, for the observed alterations in immunity and infection in studies of poor sleep and long-haul travel [33]; and in studies investigating the influence of overreaching and mal-adaptation on immune health in athletes; where depressed mood is a common feature [28, 48]. Indeed, evidence now points to a modulating effect of anxiety and perceived stress on the immune response to exercise [49] and the risk of URI in highly active individuals [50].

\section{How Does Nutrition Influence Immunity and Infection?}

The immune system's ability to clear viruses, bacteria and other pathogens, termed 'resistance', is dependent upon an adequate supply of energy from important fuel sources; including, glucose, amino acids and fatty acids. In addition to fuel requirements, cell proliferation requires nucleotides for DNA and RNA synthesis and amino acids for 
protein synthesis. An adequate supply of amino acids is also required for the production of proteins such as immunoglobulins, cytokines and acute-phase proteins [51]. The influence of severe restriction of all nutrients (Marasmus) and protein-energy-malnutrition (Kwashiorkor) on immunity and infection-related mortality in developing countries is well documented [52,53] (see also Sect. 4). Severe energy restriction may also influence immunity via activation of the hypothalamic-pituitary-adrenal axis and increases in stress hormones: cortisol, for example, is widely acknowledged to have anti-inflammatory effects [31]. Micronutrients play important roles in nucleotide and nucleic acid synthesis (e.g. iron, zinc and magnesium) and antioxidant defences that limit tissue damage (e.g. vitamins $\mathrm{C}$ and E). Antioxidant availability (e.g. vitamin C) may be particularly important during heavy exertion or infection when oxidative stress increases [54]. Some micronutrients can directly influence immune cell functions by regulating gene expression (e.g. vitamin D) $[51,55]$.

There are other ways in which nutrition may affect immunity and infection; for example, prebiotics and probiotics may influence immunity indirectly by modifying the gut microbiota [56] and elemental zinc in oral lozenges may directly inhibit viral activity in the oropharyngeal region, with purported therapeutic benefits for URI [57]. Calder highlights the bi-directional link between nutrition, immunity and infection [51]. On the one hand, malnutrition has a well-described negative influence on immunity and resistance to infection; but on the other hand, the widely reported increase in energy requirement during infection paradoxically coincides with reduced appetite (anorexia) and nutrient malabsorption, hitherto a poorly described phenomenon (see Sect. 4).

\section{Does Energy Deficiency Decrease Immunity and Increase Infection in Athletes?}

There has been much debate of late about the influence of energy deficiency on athlete health $[58,59]$. Interest in this topic has been stoked by the recent observation that low energy availability was associated with increased illness symptoms in elite female athletes [4, 5]. Besides the obvious limitation that this observation was restricted to female athletes, the authors recognised the need for studies to directly assess energy availability (they used the LEAF questionnaire) and perform measures of immunity and pathology, the latter to confirm infection. These findings are undoubtedly interesting but somewhat at odds with the instructive literature on the influence of anorexia nervosa and protein-energy-malnutrition on immunity and infection; and the findings of studies examining immunity during moderate and severe energy restriction in athletic and non-athletic populations.

Paradoxically, anorexia nervosa is considered to be protective against infection, at least until the condition is extremely severe (body mass index $[\mathrm{BMI}]<15 \mathrm{~kg} / \mathrm{m}^{2}$ ) [60-62]; moreover, infections are reported to occur readily upon refeeding $[63,64]$. Recent research sheds some light on this paradox by showing that anorexia improves immune tolerance and survival during bacterial infection ('starve a fever ...') yet potentiates the progression and lethality of viral infection ('... feed a cold') [65]. Immunity is surprisingly well preserved in patients with anorexia nervosa. Patients tend to have increased infections only in the most advanced states of hospitalisation; typically when $\geq 40 \%$ body weight has been lost and there is evidence of decreased cell-mediated immunity (delayedtype hypersensitivity), and decreased humoral immunity (serum immunoglobulins); although the latter is less markedly affected $[61,66]$. Analogous are the findings of decreased cellular immunity (lymphoid atrophy, lower T-lymphocyte counts and function, delayed-type hypersensitivity) and increased infections in malnourished children with severely advanced Kwashiorkor $(<70 \%$ body weight to height recommendation) $[52,67,68]$. Failure to meet the significantly raised energy demands during infection likely accounts for the poor infectious outcomes in the most severe cases of anorexia nervosa and proteinenergy-malnutrition [68]. The key feature of Kwashiorkor, widely recognised to suppress immunity and increase infection incidence, is low protein intake [52]. The wellpreserved immunity and robust infection resistance typical in patients with anorexia nervosa is likely because protein intake is relatively sufficient (carbohydrate and fat intake are typically reduced) [69], unlike the situation in starvation where protein deficiency is considered largely responsible for immune suppression, e.g. reduced lymphocyte proliferation [70]. The important influence of dietary protein on immunity has been demonstrated in mice challenged with influenza [71]. Mice fed a very low protein diet exhibited lower virus-specific antibody responses, lower influenza specific $\mathrm{CD} 8^{+} \mathrm{T}$ lymphocyte counts and rapid mortality after influenza infection, compared with an isocaloric adequate protein diet. Importantly, increasing protein intake in the mice fed the very low protein diet improved protective immunity. Turning our attention back to elite female athletes with low energy availability, protein intake appears to be more than adequate to support immunity; typically exceeding both government recommendations $(0.8-0.9 \mathrm{~g} / \mathrm{kg} /$ day $)$ and those proposed for endurance athletes $(1.2-1.7 \mathrm{~g} / \mathrm{kg} /$ day $)[72,73]$. For example, in a group of elite female distance runners with low energy availability (BMI $18.9 \mathrm{~kg} / \mathrm{m}^{2}$ ), protein 
intake was $2.1 \mathrm{~g} / \mathrm{kg} / \mathrm{day}$, and in those with amenorrhea (BMI $18.5 \mathrm{~kg} / \mathrm{m}^{2}$; absence of menses $\geq 3$ months), protein intake was $2.4 \mathrm{~g} / \mathrm{kg} /$ day [73]. As such, there must be some other explanation for the increased URI reports in elite female athletes with low energy availability. It is conceivable that poor mental health (e.g. stress, anxiety and depression), highly prevalent in female athletes with low energy availability $[4,74,75]$, plays a role in the increased URI reports: psychological stress, anxiety and depression have a well-known and marked influence on immunity and infection resistance $[44,76]$. Research is required to solve the puzzle that anxiety disorders and depression are also highly comorbid with anorexia nervosa [77, 78], yet this condition appears to provide some protection against URI [60-62].

The findings from randomised controlled trials are also informative in answering the question; does energy deficiency decrease immunity and increase infection in athletes? A $25 \%$ calorie restriction, over a 2 -year period in non-obese adults (BMI $25.1 \mathrm{~kg} / \mathrm{m}^{2}$ ), resulted in a $10 \%$ body weight loss but did not decrease in-vivo cell-mediated immunity (skin delayed-type hypersensitivity test) or antibody responses to $\mathrm{T}$ - and B-cell-mediated vaccinations (hepatitis A, tetanus/ diphtheria and pneumococcal); and had no effect on clinical infections [79]. On the contrary, the authors observed salubrious benefits of moderate calorie restriction, without malnutrition, on inflammation; as demonstrated by $40-50 \%$ lower circulating $\mathrm{C}$-reactive protein and tumour necrosis factor- $\alpha$. These inflammatory molecules have well-established roles in the pathogenesis of multiple chronic diseases and aging; as such, the findings align with the contemporary view that dietary restriction without malnutrition elicits a healthy phenotype and extends the lifespan [79-81]. Of course, the findings of research examining the influence of long-term moderate energy deficits on immunity in non-obese adults are interesting but arguably of limited relevance to athletic populations. For example, there are obvious population differences in body composition (average BMI of $25.1 \mathrm{~kg} / \mathrm{m}^{2}$ is considered overweight [79]) and the energy deficit in athletic populations typically results from high energy expenditure during heavy training, rather than calorie restriction. Notwithstanding, studies in athletic and military populations investigating short-term severe energy restriction ( $48 \mathrm{~h}, \sim 90 \%$ restriction) and long-term moderate energy restriction during training ( 8 weeks, $\sim 25 \%$ restriction) show only subtle and short-lived changes in immunity [82-84]; and no increase in the immune-modulating hormone, cortisol. Concordant with these findings, low energy availability in female and male endurance athletes has little effect on circulating cortisol [85]. This is perhaps not surprising as a recent meta-analysis showed that circulating cortisol increases in states of complete fasting but typically not during less severe energy restriction [86]. It is a common misconception, and an oversimplification, that increases in circulating cortisol always decrease immunity [87]; the reality is more nuanced. For example, increases in circulating cortisol during short-term stress (lasting minutes to hours) can have adjuvant-like effects that enhance immunity [31, 88]. In contrast, chronic stress (lasting days to months) can disrupt the cortisol circadian rhythm and increase glucocorticoid resistance, with harmful effects on immunity, inflammation and infection resistance [31, 89]. In summary, direct evidence to support the notion that energy deficiency of the magnitude often reported in elite female athletes compromises immunity is currently lacking.

\section{New Theoretical Perspective on Nutrition and Athlete Immune Health}

Traditionally, immunologists have focused their efforts on understanding the immune weaponry at our disposal in the fight against infectious pathogens (termed 'resistance'). Ecological immunologists prefer a model describing not only resistance but also 'tolerance', defined as the ability to endure a microbe [7, 90]. Ayres and Schneider elegantly describe a paradigm using these concepts 'resistance' and 'tolerance' to better understand human-pathogen interactions [91]. Using a castle metaphor, they describe the inhabitants of the fortress performing various tasks; including, repairing the walls, raising offspring and distributing food. At the same time, the inhabitants must decide whether a battle is worth fighting and the appropriate weapons to use: the immune equivalent of 'choosing your battles wisely'. Key to effective tolerance is a proportionate immune response: an overly exuberant immune response can cause excessive tissue damage and unnecessarily allocate energy resources away from vital functions; vice-versa, a weak immune response increases susceptibility to damage from the pathogen (Fig. 1) [91].

Reactive oxygen species play an important role in host defence against infection but increased oxidative stress during an immune reponse can result in collateral tissue damage, placing an increased demand on antioxidant scavenging during infection. Seminal research in bumblebees has demonstrated the cost of full-blown immune activation for host survival: starvation significantly decreased survival time in immune-activated compared with immune-naïve bumblebees [92]. Given the tissue damage and increased energy cost during a full-blown immune response, the immune system has likely evolved to control persistent infection at a non-damaging level and exhibit tolerance to non-threatening organisms (Fig. 1) [7, 91, 93]. A prime example is the mutualistic bacteria that reside in the gut; the immune system does not raise a pathogenic response to obliterate the grams of lipopolysaccharide in the intestinal lumen 


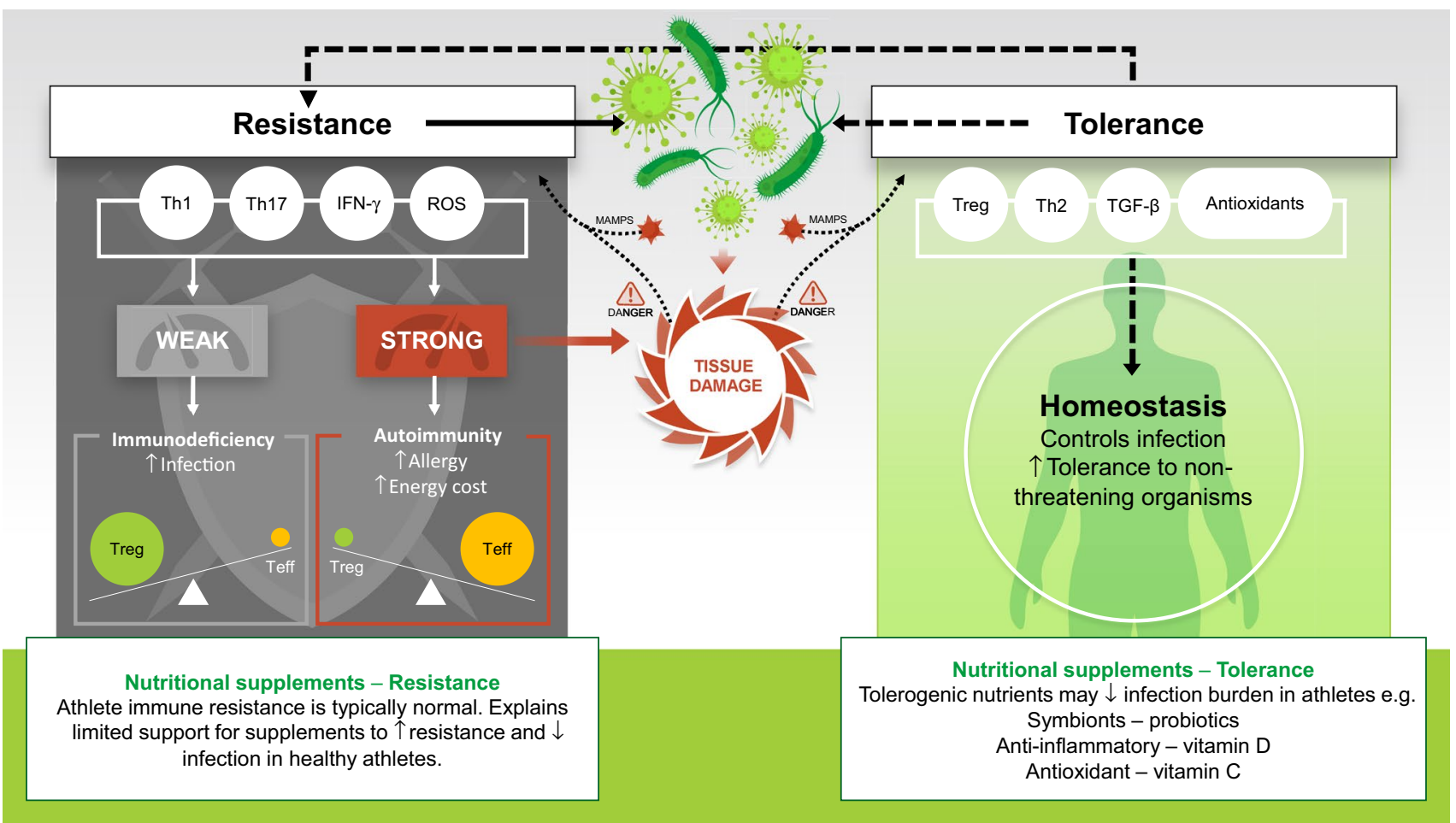

Fig. 1 Model of resistance and tolerance in host-pathogen interactions: value of nutritional supplementation. Dark shaded area on the left (arrows with solid lines) shows classical view of immune 'resistance' where the immune weaponry protects the host by attempting to reduce the pathogen burden, e.g. through cell-mediated killing and release of reactive oxygen species (ROS). Weak resistance results in immunodeficiency and increased risk of infection. In contrast, an overly exuberant immune response to a pathogen causes tissue damage and wasteful diversion of energy resources away from other important functions. An overly strong immune response is associated with autoimmunity and allergy. In this simple model, homeostasis is achieved by balancing effector and regulatory sides of the scales. This classical model of immune homeostasis overlooks important tolerogenic interactions with the pathogen. The concept of 'tolerance', the ability to endure microbes, (light green shaded area on the right and arrows with broken lines) has been adopted from ecological immu-

[94]. Co-stimulation, by microbe-associated molecular patterns (MAMPS) and danger signals from damaged tissue, is required for full immune activation. In addition, the localisation of MAMPS and associated pattern recognition receptors at the base of intestinal crypts limits contact with non-pathogenic microbes; together, co-stimulation and spatial localisation of MAMPS facilitate host tolerance to mutualistic bacteria that reside in the gut $[91,93,95]$. Evolution has preferentially selected non-toxic effectors and receptors, in accordance with this model of tolerance; for example, antimicrobial peptides are more toxic to pathogens than to self and Toll-like receptors have a higher affinity for pathogen-associated molecules [94]. Homeostasis is achieved by an appropriate balance of resistance and tolerance that allows us to fight infection, where the signals indicate this nology where work in invertebrates shows important tolerogenic interactions between the host and microbes, the findings of which are generalisable to vertebrates [91, 93]. Pathogens influence the magnitude of the immune response by displaying microbe-associated molecular patterns (MAMPS) and by stimulating the release of danger signals from damaged tissue. Tolerance in this model dampens defence activity (upper broken arrow) yet controls infection at a nondamaging level, with the added benefit of a lower energy cost. This explains how we tolerate commensal bacteria rather than eliciting an immune response to obliterate the large abundance of bacteria in the gut. This model also helps to explain why nutritional supplements with tolerogenic effects may reduce the burden of infection (e.g. reduced severity and duration) in otherwise healthy athletes. IFN- $\gamma$ interferon gamma, Teff effector T cells, TGF- $\beta$ transforming growth factor-beta, $T h \mathrm{~T}$-helper lymphocyte, Treg regulatory $\mathrm{T}$ cells

is necessary, yet maintain a healthy relationship with the mutualistic bacteria in our gut (Fig. 1).

This new theoretical perspective may improve our understanding of how sick we will become when we have an infection (in terms of severity and duration) [7], and more clearly elucidate a role for nutrition, particularly in terms of tolerance (Fig. 1, Sect. 5.2). Of course, it stands to reason that a frank deficiency of a nutrient required for proper immune function will decrease immune resistance and increase susceptibility to infection. Examples include the well-known influence of dietary protein deficiency on host defence (Sect. 4) $[52,70,71]$ and evidence that a frank deficiency in zinc decreases immunity [96]. However, growing evidence indicates that for some nutrients there are times when intakes above recommended levels may have beneficial effects on 
immunity [97]; likely by optimising the delicate balance between resistance and tolerance.

Looking through this new lens, illustrated in Fig. 1, brings into sharp focus the hitherto rather mixed picture presented by studies investigating nutritional supplements and athlete immune health. For example, this model helps to explain why nutritional supplements with tolerogenic effects may reduce the burden of infection in otherwise healthy athletes (e.g. reduced severity and duration) (Sect. 5.2). Clearly, its no longer sufficient to ask only if a nutritional intervention will stop the athlete getting sick; perhaps its more pertinent to ask, will the nutritional intervention reduce how sick the athlete will get?

\subsection{Nutritional Supplements for Immune Resistance: If it Ain't Broke, Don't Fix it!}

As logic would dictate, support for nutritional supplements to improve immune resistance (and thus decrease pathogen burden) comes largely from studies in those with impaired immunity, such as the frail elderly and clinical patients; particularly in those with poor nutritional status [51, 97]. Over the last 25 years or so, exercise immunologists have actively researched nutritional supplements to improve immune resistance in athletes (Table 1). For much of this period, there was a broad acceptance amongst exercise immunologists that immunity was impaired in athletes under heavy training; prompting the search for nutritional countermeasures $[98,99]$. A more contemporary view is that the evidence supporting immunosuppression in athletes is lacking $[39,41]$. Thus, it is not surprising that supplements targeted towards immune resistance show limited benefits for athlete immunity and host defence: the phrase 'if it ain't broke, don't fix it' comes to mind (Table 1). One exception is the therapeutic effect of zinc lozenges for treating the common cold. A recent meta-analysis showed that zinc lozenges $(75 \mathrm{mg} /$ day of elemental zinc) reduced URI duration by $\sim 3$ days (33\%) when taken $<24 \mathrm{~h}$ after the onset of symptoms, and for the duration of the illness [57]. Hemilä points out that the optimal zinc lozenge dosage and composition need to be determined; indeed, many over-the-counter lozenges contain too little zinc or contain substances that bind zinc [57].

Although the exact mechanism(s) require elucidation, zinc may act as an antiviral agent by increasing interferon gamma and decreasing the docking of common cold viruses with binding sites; the latter by decreasing levels of intercellular adhesion molecule-1 $[100,101]$. The therapeutic effects of zinc lozenges for treating URI have also been ascribed to antioxidant and anti-inflammatory properties of elemental zinc in the lozenge [102]; as such, zinc lozenges may also have tolerogenic effects on immunity.

\subsection{Tolerogenic Nutritional Supplements: The New Targets}

Tolerance in this model dampens defence activity yet effectively controls infection at a non-damaging level; it also facilitates homeostatic regulation of beneficial intestinal microbial communities (Fig. 1). Looking through this lens it is easy to see why studies involving nutritional supplements with tolerogenic properties have yielded some positive effects for reducing the burden of infection in otherwise healthy athletes (Table 2). Probiotics (and prebiotics) may have tolerogenic effects by influencing intestinal microbial communities and the common mucosal immune system [56]; the antioxidant effects of vitamin $\mathrm{C}$ and the anti-inflammatory effects of vitamin D may improve tolerance, mitigating against excessive tissue damage during infection [54, 55, 91]. As mentioned previously, the therapeutic effects of zinc lozenges for treating the common cold, although principally considered to reduce the pathogen burden (improved resistance), have also been attributed to antioxidant and antiinflammatory (tolerogenic) properties of zinc [102].

\subsubsection{Probiotics}

Probiotics are live microorganisms that when administered regularly and in adequate amounts are thought to confer a health benefit on the host by modulating gut-dwelling bacteria (the microbiota) and immunity [137]. There are various mechanisms by which probiotics are purported to benefit immunity and infection resistance, particularly respiratory and gastrointestinal infections; however, thus far these have not been clearly elucidated [97]. Probiotics can improve immune resistance by reinforcing the intestinal barrier and competing with pathogens for both attachment to the gut epithelium and for available nutrients. The products of probiotic metabolism (e.g. lactic acid) can also inhibit pathogen growth in the gut [138]. Probiotics are considered to have important mutualistic benefits for immune health that extend beyond the gut; these interactions between the commensal microbial community and the host immune system occur via the common mucosal immune system [139]. There is now broad agreement that probiotics exert important antiinflammatory 'tolerogenic' effects that maintain homeostasis (Fig. 1); for example, probiotics may prevent unnecessary inflammatory responses to harmless foreign substances in the gut [97].

Results from studies investigating the influence of probiotics on athlete immune health are promising and interested readers are directed to extensive reviews on the subject [56, 139]. One placebo-controlled cross-over trial in 20 elite distance runners showed that probiotic supplementation 


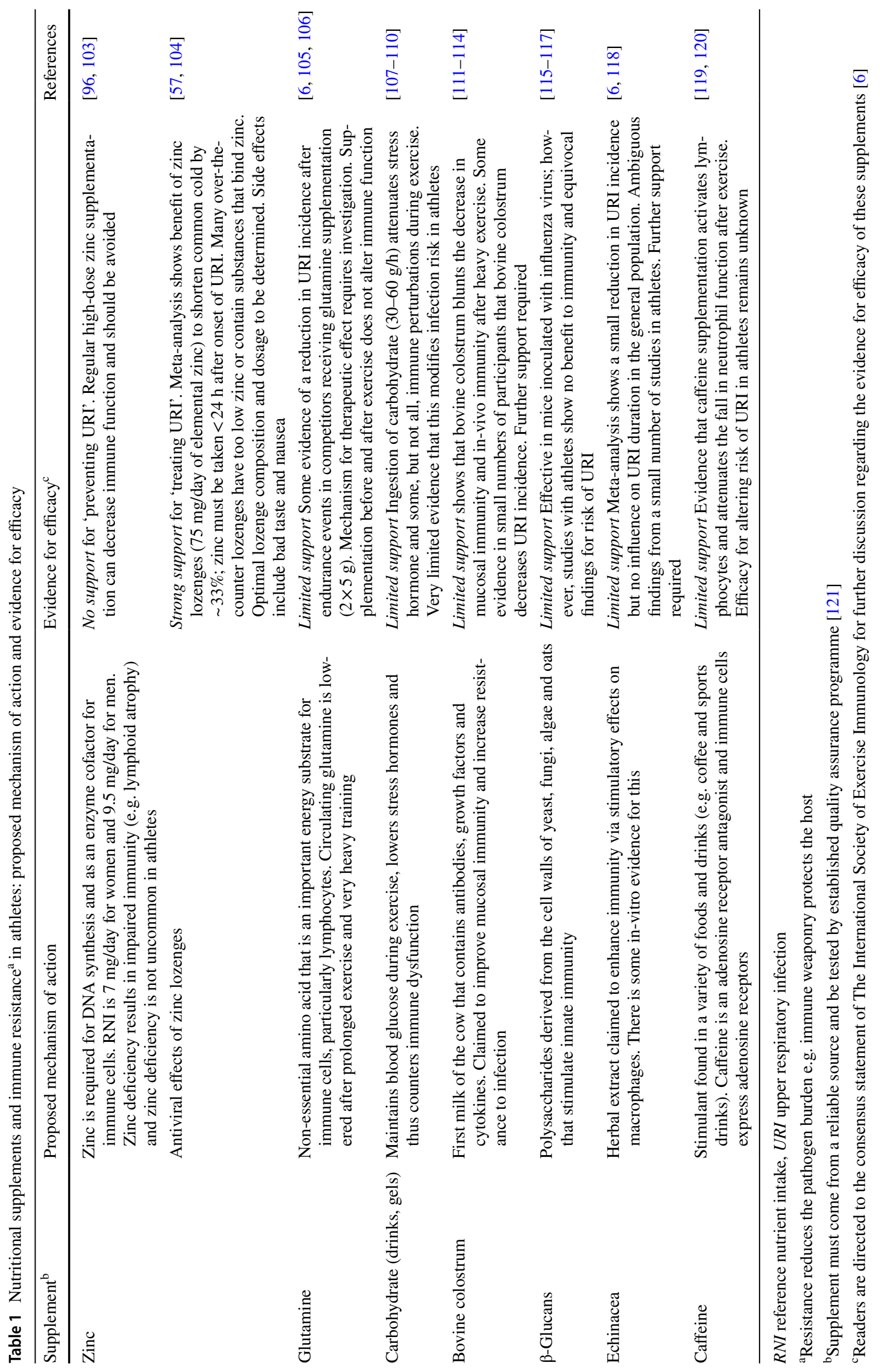




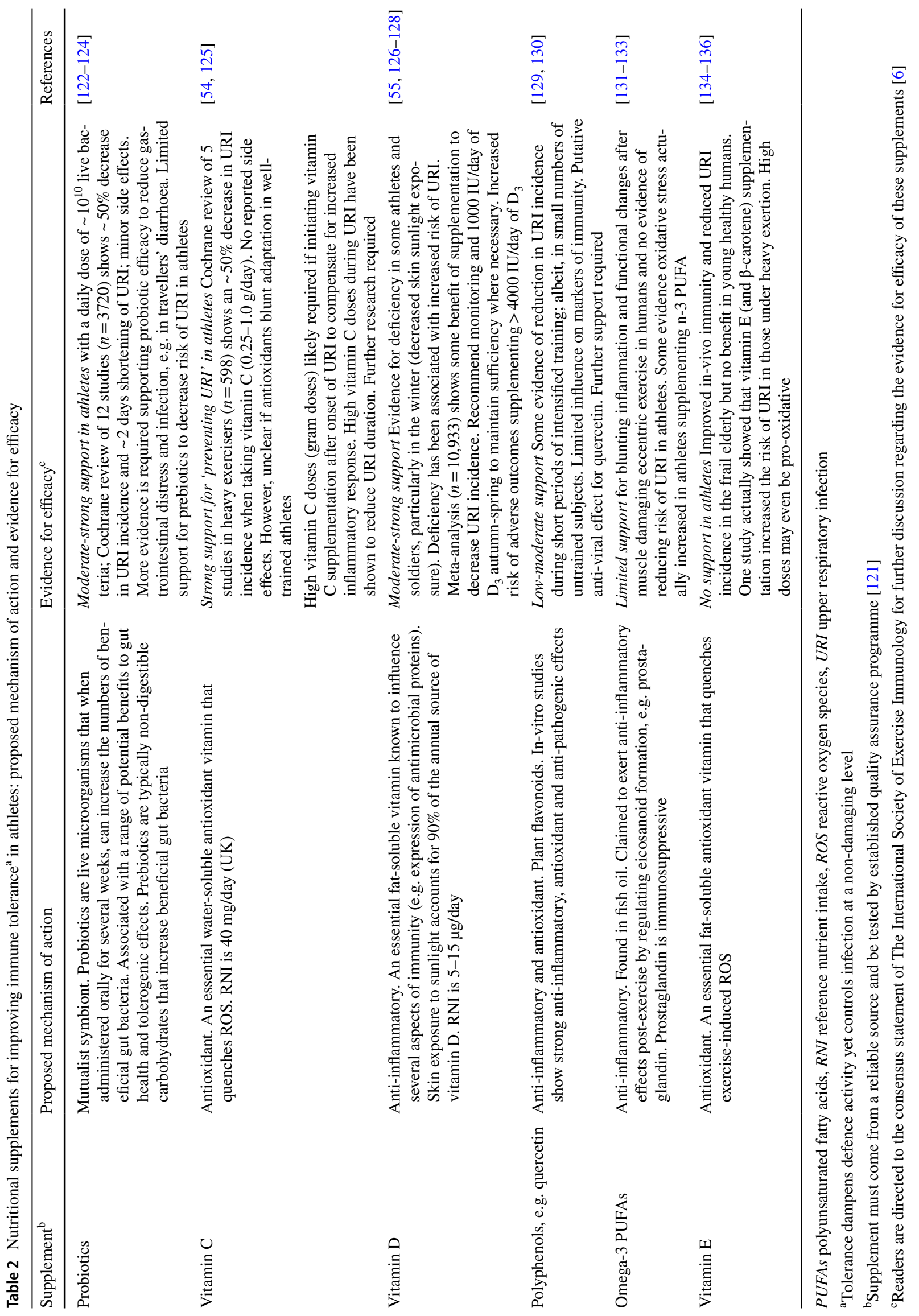


(Lactobacillus fermentum) for 28 days reduced the number of days of URI and the severity of URI symptoms [140]. Another randomised placebo-controlled trial in 64 university athletes reported a lower incidence of URI during a 4-month winter training period in athletes receiving a daily probiotic (Lactobacillus casei Shirota) compared with placebo; this study also reported better maintenance of saliva secretory immunoglobulin-A in the probiotic group [122]. Four weeks of supplementation with a multi-species probiotic formulation (Lactobacillus, Bifidobacterium and Streptococcus) reduced markers of gut permeability and symptoms of gastrointestinal discomfort during exerciseheat-stress [141]. The conclusions of another study were that supplementing marathon runners $(n=61)$ with Lactobacillus rhamnosus daily (vs. placebo $n=58$ ) for 3 months before a marathon led to shorter lasting gastrointestinal symptoms during the 2 weeks after the race ( 1 vs. 2.3 days in placebo) [142]. Caution is needed when interpreting these findings as the percentage of runners who actually experienced gastrointestinal symptom episodes during the 2 weeks after the marathon was, as one might expect, low (4\% in each group). As such, the sample the authors base their rather speculative conclusion on was small (only two to three runners in each group) [30]. Whether probiotics and prebiotics can prevent travellers' diarrhoea remains unclear and there is some evidence that prophylaxis is dependent upon the strain of probiotic given [123]. Notwithstanding, results from general population studies show some beneficial effects of probiotics on URI (Table 2). A recent meta-analysis showed that probiotic supplementation reduced the incidence of URI by approximately half, shortened URI duration by approximately 2 days, reduced antibiotic prescription rates and resulted in only minor side effects [124]. However, only 12 studies were included in the meta-analysis $(n=3720)$ and the quality of evidence was rated as low; limitations included the relatively small sample sizes, poor controls and unclear procedures for randomisation. Although the available evidence supporting probiotics to reduce the infection burden in athletes is by no means definitive, studies to date indicate some benefit with little evidence of harm. Athletes might therefore consider probiotic supplementation particularly during periods of increased URI risk, e.g. in the weeks before and during foreign travel [139].

\subsubsection{Vitamin C}

Vitamin C (ascorbic acid) is a major water-soluble antioxidant that is effective as a scavenger of reactive oxygen species in both intracellular and extracellular fluids. Good sources of vitamin $\mathrm{C}$ include fruit and vegetables and the reference nutrient intake for adults is $40 \mathrm{mg} /$ day (UK).
Vitamin $\mathrm{C}$ is found in high concentrations in leucocytes but the level falls dramatically during a common cold, when oxidative stress increases [143]. As such, there is a a sound scientific basis for vitamin $\mathrm{C}$ supplementation to improve tolerance by mitigating against excessive tissue damage during infection [91]. There is also a strong rationale for anticipating benefits to reduce URI in athletes who experience increased oxidative stress during heavy exercise [144]. A recent review and a meta-analysis have examined the evidence that daily doses of vitamin $\mathrm{C}$ of more than $200 \mathrm{mg}$ have prophylactic and therapeutic effects for the common cold [54, 125]. In a subgroup of five placebo-controlled trials in heavy exercisers $(n=598)$, including marathon runners, skiers and soldiers, vitamin $\mathrm{C}(0.25-1.0 \mathrm{~g} / \mathrm{day})$ decreased URI incidence by $52 \%$ [125]. For example, in a double-blind placebo-controlled design, Peters and colleagues showed that $600 \mathrm{mg} / \mathrm{day}$ of vitamin $\mathrm{C}$ for 3 weeks prior to a $90-\mathrm{km}$ ultramarathon reduced the incidence of URI symptoms in the 2 -week post-race period (33\% vs. $68 \%$ in age- and sex-matched control runners) [145]. Whether the observed benefit of vitamin $\mathrm{C}$ for preventing URI symptoms in those under heavy exertion represents a real decrease in respiratory viral infection is an important avenue for inquiry. The rather high URI symptom incidence in the Peters et al. study (68\% in placebo) and the observed benefit of vitamin $\mathrm{C}$ might relate to exercise-induced bronchoconstriction caused by airway inflammation and injury, which is common during heavy exercise [146, 147]. Regardless of the mechanism, there are clear benefits of vitamin C supplementation $(0.25-1.0 \mathrm{~g} /$ day $)$ to reduce URI symptoms in athletes (Table 2).

Determining whether initiating vitamin C supplementation after the onset of URI has therapeutic effects is complicated by methodological differences between studies, e.g. differences in the timing of initiating vitamin $C$ supplementation and differences in the duration and dosage of supplementation [125]. Higher daily vitamin $\mathrm{C}$ doses may be required for treating URI; for example, $200 \mathrm{mg} /$ day of vitamin $C$ was insufficient to restore leukocyte vitamin $C$ levels during URI but at $6 \mathrm{~g} /$ day the decline in vitamin $\mathrm{C}$ levels was abolished [143]. Providing $8 \mathrm{~g}$ of vitamin $\mathrm{C}$ on the first day of a URI shortened URI duration more than $4 \mathrm{~g}$ [148] and dose-dependent benefits were shown in another trial providing $3 \mathrm{~g} /$ day and $6 \mathrm{~g} /$ day of vitamin C [149]. Hemilä et al. suggest that future therapeutic trials in adults should use doses that exceed $8 \mathrm{~g} /$ day of vitamin C [125].

One area of uncertainty is whether regular high-dose vitamin $\mathrm{C}$ supplementation ( $1 \mathrm{~g} / \mathrm{day})$ blunts some of the adaptations to endurance training $[150,151]$. The authors of one study caution against high-dose antioxidant supplementation during endurance training to avoid blunting cellular adaptations [152]. However, whether high-dose antioxidant supplementation blunts training adaptations in 
highly trained athletes has been questioned [153]. As vitamin C supplementation $(0.25-1.0 \mathrm{~g} /$ day $)$ is cheap, safe and can prevent URI symptoms in those under heavy exertion, athletes should consider vitamin $\mathrm{C}$ supplementation during periods of heightened infection risk, e.g. foreign travel for important competition.

\subsubsection{Vitamin D}

In 1981, the British general practitioner and celebrated epidemiologist, R. Edgar Hope-Simpson was the first to hypothesise that respiratory viral infections (e.g. epidemic influenza) have a 'seasonal stimulus' intimately associated with solar radiation. The nature of this 'seasonal stimulus' remained undiscovered until the important immunomodulatory effects of the sunlight-dependent secosteroid vitamin $\mathrm{D}$ were fully recognised $[154,155]$. Vitamin D production as a result of sunlight ultraviolet $\mathrm{B}$ radiation penetrating the skin typically provides $80-100 \%$ of the body's vitamin D requirements, with a small amount typically coming from the diet (good sources include oily fish and egg yolks). The recommended daily dietary intake of vitamin $\mathrm{D}$ for adults ( $5 \mu \mathrm{g}$ or $200 \mathrm{IU}$ in the European Union and $15 \mu \mathrm{g}$ or $600 \mathrm{IU}$ in the USA) assumes that no synthesis occurs and all of a person's vitamin D is from food intake, although that will rarely occur in practice [55]. It is now clear that vitamin D has important roles beyond its well-known effects on calcium and bone homeostasis. Immune cells express the vitamin $\mathrm{D}$ receptor, including antigen-presenting cells, $\mathrm{T}$ cells and B cells, and these cells are all capable of synthesising the biologically active vitamin D metabolite, 1,25-hydroxy vitamin D. It is widely accepted that vitamin D plays an important role in enhancing innate immunity via the induction of antimicrobial proteins; yet many of the actions of vitamin $\mathrm{D}$ on acquired immunity are anti-inflammatory in nature. Tolerogenic effects of vitamin D (Fig. 1) prevent overly exuberant immune responses following T-cell activation (e.g. 1,25-hydroxy vitamin $\mathrm{D}$ induces development of regulatory $\mathrm{T}$ cells and inhibits production of interferongamma) [55]. There has been growing interest in the benefits of supplementing vitamin $\mathrm{D}$ as studies report vitamin D insufficiency (circulating $25(\mathrm{OH}) \mathrm{D}<50 \mathrm{nmol} / \mathrm{L}$ ) in more than half of all athletes and military personnel tested during the winter, when skin sunlight ultraviolet $B$ is negligible $[156,157]$. The overwhelming evidence supports avoiding vitamin D deficiency (circulating $25(\mathrm{OH}) \mathrm{D}<30 \mathrm{nmol} / \mathrm{L}$ ) to maintain immunity and reduce the burden of URI in the general population, athletes and military personnel [158-160]. A recent meta-analysis reported protective effects of oral vitamin D supplementation on respiratory infection (odds ratio 0.88 ); particularly in those deficient for vitamin $\mathrm{D}$ at baseline (odds ratio 0.30 ) and in those who received oral vitamin D daily or weekly, but not in those receiving one or more large boluses [126]. Vitamin D sufficiency can be achieved by safe sunlight exposure in the summer $[127,161$, 162 ] and where screening indicates insufficiency, $1000 \mathrm{IU} /$ day vitamin $\mathrm{D}_{3}$ supplementation in the winter (Table 2) [55, 127].

\section{Conclusions}

This review provides a new theoretical perspective on how nutrition influences athlete immune health. A paradigm recently adopted from ecological immunology is presented that includes immune resistance (ability to destroy microbes) and immune tolerance (ability to dampen an immune response and control infection at a non-damaging level). Through this new lens, it is easy to see why studies investigating nutritional supplements targeted at improving immune resistance in athletes show limited benefits: evidence supporting immune suppression in athletes is lacking; viz. if it ain't broke, don't fix it! This new perspective sharpens the focus on nutritional supplements with beneficial tolerogenic properties that reduce the infection burden in otherwise healthy athletes; including, probiotics, vitamin $\mathrm{C}$ and vitamin $\mathrm{D}$. Further research is required to demonstrate the benefits of candidate tolerogenic nutritional supplements to reduce the infection burden in athletes; without blunting training adaptations and without side effects. When considering nutritional supplementation, athletes must check the supplement comes from a reliable source and is tested by an established quality assurance programme [121].

Acknowledgements This supplement is supported by the Gatorade Sports Science Institute (GSSI). The supplement was guest edited by Lawrence L. Spriet, who attended a meeting of the GSSI Expert Panel in March 2019 and received honoraria from the GSSI, a division of PepsiCo, Inc., for his participation in the meeting. Dr. Spriet received no honoraria for guest editing the supplement. Dr. Spriet suggested peer reviewers for each paper, which were sent to the Sports Medicine Editor-in-Chief for approval, prior to any reviewers being approached. Dr. Spriet provided comments on each paper and made an editorial decision based on comments from the peer reviewers and the Editorin-Chief. Where decisions were uncertain, Dr. Spriet consulted with the Editor-in-Chief. The author Professor Neil Walsh is no longer at Bangor University and is currently at the Research Institute for Sport and Exercise Science, Liverpool John Moores University, Liverpool, UK.

\section{Compliance with Ethical Standards}

Funding This article is based on a presentation by Neil P. Walsh to the Gatorade Sports Science Institute Expert Panel in March 2019. The Gatorade Sports Science Institute provided funding for attendance at that meeting together with an honorarium for preparation of this article.

Conflict of interest Neil P. Walsh has no conflicts of interest that are directly relevant to the content of this article. 
Open Access This article is distributed under the terms of the Creative Commons Attribution 4.0 International License (http://creativeco mmons.org/licenses/by/4.0/), which permits unrestricted use, distribution, and reproduction in any medium, provided you give appropriate credit to the original author(s) and the source, provide a link to the Creative Commons license, and indicate if changes were made.

\section{References}

1. Leyton GB. Effects of slow starvation. Lancet. 1946;2(6412):73-9.

2. Field CJ, Johnson IR, Schley PD. Nutrients and their role in host resistance to infection. J Leukoc Biol. 2002;71(1):16-32.

3. Shephard RJ, Shek PN. Heavy exercise, nutrition and immune function: is there a connection? Int J Sports Med. 1995;16(8):491-7. https://doi.org/10.1055/s-2007-973043.

4. Drew M, Vlahovich N, Hughes D, et al. Prevalence of illness, poor mental health and sleep quality and low energy availability prior to the 2016 summer olympic games. Br J Sports Med. 2018;52(1):47-53. https://doi.org/10.1136/bjsports-2017-09820 8.

5. Drew MK, Vlahovich N, Hughes D, et al. A multifactorial evaluation of illness risk factors in athletes preparing for the summer olympic games. J Sci Med Sport. 2017;20(8):745-50. https://doi. org/10.1016/j.jsams.2017.02.010.

6. Bermon S, Castell LM, Calder PC, et al. Consensus statement immunonutrition and exercise. Exerc Immunol Rev. 2017;23:8-50.

7. McCarville JL, Ayres JS. Disease tolerance: concept and mechanisms. Curr Opin Immunol. 2018;50:88-93. https://doi. org/10.1016/j.coi.2017.12.003.

8. Palmer-Green D, Fuller C, Jaques R, et al. The injury/illness performance project (IIPP): a novel epidemiological approach for recording the consequences of sports injuries and illnesses. J Sports Med (Hindawi Publ Corp). 2013;2013:523974. https:// doi.org/10.1155/2013/523974.

9. Engebretsen L, Soligard T, Steffen K, et al. Sports injuries and illnesses during the london summer olympic games 2012. Br J Sports Med. 2013;47(7):407-14. https://doi.org/10.1136/bjspo rts-2013-092380.

10. Soligard T, Steffen K, Palmer-Green D, et al. Sports injuries and illnesses in the sochi 2014 olympic winter games. Br J Sports Med. 2015;49(7):441-7. https://doi.org/10.1136/bjsports-2014094538.

11. Hellard P, Avalos M, Guimaraes F, et al. Training-related risk of common illnesses in elite swimmers over a 4-yr period. Med Sci Sports Exerc. 2015;47(4):698-707. https://doi.org/10.1249/ MSS.0000000000000461.

12. Svendsen IS, Taylor IM, Tonnessen E, et al. Training-related and competition-related risk factors for respiratory tract and gastrointestinal infections in elite cross-country skiers. Br J Sports Med. 2016;50(13):809-15. https://doi.org/10.1136/ bjsports-2015-095398.

13. Martensson S, Nordebo K, Malm C. High training volumes are associated with a low number of self-reported sick days in elite endurance athletes. J Sports Sci Med. 2014;13(4):929-33.

14. Van Tonder A, Schwellnus M, Swanevelder S, et al. A prospective cohort study of 7031 distance runners shows that 1 in 13 report systemic symptoms of an acute illness in the 8-12 day period before a race, increasing their risk of not finishing the race 1.9 times for those runners who started the race: safer study iv. Br J Sports Med. 2016;50(15):939-45. https://doi. org/10.1136/bjsports-2016-096190.

15. Ekblom B, Ekblom O, Malm C. Infectious episodes before and after a marathon race. Scand J Med Sci Sports. 2006;16(4):28793. https://doi.org/10.1111/j.1600-0838.2005.00490.x.

16. Weidner TG, Sevier TL. Sport, exercise, and the common cold. J Athl Train. 1996;31(2):154-9.

17. Roberts JA. Viral illnesses and sports performance. Sports Med. 1986;3(4):298-303. https://doi.org/10.2165/00007256198603040-00006.

18. Tseng GS, Hsieh CY, Hsu CT, et al. Myopericarditis and exertional rhabdomyolysis following an influenza A (H3N2) infection. BMC Infect Dis. 2013;13:283. https://doi. org/10.1186/1471-2334-13-283.

19. Kiel RJ, Smith FE, Chason J, et al. Coxsackievirus b3 myocarditis in $\mathrm{C} 3 \mathrm{H} / \mathrm{HEJ}$ mice: description of an inbred model and the effect of exercise on virulence. Eur J Epidemiol. 1989;5(3):348-50.

20. Shephard RJ, Shek PN. Immune dysfunction as a factor in heat illness. Crit Rev Immunol. 1999;19(4):285-302.

21. Rav-Acha M, Hadad E, Epstein Y, et al. Fatal exertional heat stroke: a case series. Am J Med Sci. 2004;328(2):84-7.

22. Periard JD, Racinais S, Timpka T, et al. Strategies and factors associated with preparing for competing in the heat: a cohort study at the 2015 IAAF World Athletics Championships. Br J Sports Med. 2017;51(4):264-70. https://doi.org/10.1136/bjspo rts-2016-096579.

23. Walsh NP, Gleeson M, Pyne DB, et al. Position statement. Part two: maintaining immune health. Exerc Immunol Rev. 2011;17:64-103.

24. Tomasi TB, Trudeau FB, Czerwinski D, et al. Immune parameters in athletes before and after strenuous exercise. J Clin Immunol. 1982;2(3):173-8.

25. Fitzgerald L. Exercise and the immune system. Immunol Today. 1988;9(11):337-9. https://doi.org/10.1016/01675699(88)91332-1.

26. Keast D, Cameron K, Morton AR. Exercise and the immune response. Sports Med. 1988;5(4):248-67.

27. Peters EM, Bateman ED. Ultramarathon running and upper respiratory tract infections: an epidemiological survey. S Afr Med J. 1983;64(15):582-4.

28. Verde T, Thomas S, Shephard RJ. Potential markers of heavy training in highly trained distance runners. Br J Sports Med. 1992;26(3):167-75.

29. Mackinnon LT, Hooper S. Mucosal (secretory) immune system responses to exercise of varying intensity and during overtraining. Int J Sports Med. 1994;15(Suppl. 3):S179-83. https://doi. org/10.1055/s-2007-1021134.

30. Gleeson M, Bishop NC, Walsh NP. Exercise immunology. Abingdon: Routledge; 2013.

31. Dhabhar FS. Effects of stress on immune function: the good, the bad, and the beautiful. Immunol Res. 2014;58(2-3):193-210. https://doi.org/10.1007/s12026-014-8517-0.

32. Peake JM, Neubauer O, Walsh NP, et al. Recovery of the immune system after exercise. J Appl Physiol. 2017;122(5):1077-87. https://doi.org/10.1152/japplphysiol.00622.2016.

33. Walsh NP. Recommendations to maintain immune health in athletes. Eur J Sport Sci. 2018;18(6):820-31. https://doi. org/10.1080/17461391.2018.1449895.

34. Gleeson M, Pyne DB. Respiratory inflammation and infections in high-performance athletes. Immunol Cell Biol. 2016;94(2):12431. https://doi.org/10.1038/icb.2015.100.

35. Bruunsgaard H, Hartkopp A, Mohr T, et al. In vivo cell-mediated immunity and vaccination response following prolonged, intense exercise. Med Sci Sport Exer. 1997;29(9):1176-81. 
36. Diment BC, Fortes MB, Edwards JP, et al. Exercise intensity and duration effects on in vivo immunity. Med Sci Sport Exer. 2015;47(7):1390-8. https://doi.org/10.1249/MSS.0000000000 000562.

37. Nieman DC. Exercise, infection, and immunity. Int $\mathbf{J}$ Sports Med. 1994;15(Suppl. 3):S131-41. https://doi. org/10.1055/s-2007-1021128.

38. Robson PJ, Blannin AK, Walsh NP, et al. Effects of exercise intensity, duration and recovery on in vitro neutrophil function in male athletes. Int J Sports Med. 1999;20(2):128-35. https:// doi.org/10.1055/s-2007-971106.

39. Walsh NP, Gleeson M, Shephard RJ, et al. Position statement. Part one: immune function and exercise. Exerc Immunol Rev. 2011;17:6-63.

40. Walsh NP, Oliver SJ. Exercise, immune function and respiratory infection: an update on the influence of training and environmental stress. Immunol Cell Biol. 2016;94(2):132-9. https://doi. org/10.1038/icb.2015.99.

41. Campbell JP, Turner JE. Debunking the myth of exercise-induced immune suppression: redefining the impact of exercise on immunological health across the lifespan. Front Immunol. 2018;9:648. https://doi.org/10.3389/fimmu.2018.00648.

42. Nieman DC, Johanssen LM, Lee JW, et al. Infectious episodes in runners before and after the Los Angeles marathon. J Sports Med Phys Fitness. 1990;30(3):316-28.

43. Wentz LM, Ward MD, Potter C, et al. Increased risk of upper respiratory infection in military recruits who report sleeping less than 6 h per night. Mil Med. 2018;183(11-12):e699-704. https ://doi.org/10.1093/milmed/usy090.

44. Cohen S, Tyrrell DA, Smith AP. Psychological stress and susceptibility to the common cold. N Engl J Med. 1991;325(9):606-12. https://doi.org/10.1056/NEJM199108293250903.

45. Cohen S, Doyle WJ, Alper CM, et al. Sleep habits and susceptibility to the common cold. Arch Intern Med. 2009;169(1):62-7. https://doi.org/10.1001/archinternmed.2008.505.

46. Schwellnus MP, Derman WE, Jordaan E, et al. Elite athletes travelling to international destinations $>5$ time zone differences from their home country have a 2-3-fold increased risk of illness. Br J Sports Med. 2012;46(11):816-21. https://doi.org/10.1136/ bjsports-2012-091395.

47. Patel D. Occupational travel. Occup Med (Lond). 2011;61(1):618. https://doi.org/10.1093/occmed/kqq163.

48. Meeusen R, Duclos M, Foster C, et al. Prevention, diagnosis, and treatment of the overtraining syndrome: joint consensus statement of the European College of Sport Science and the American College of Sports Medicine. Med Sci Sports Exerc. 2013;45(1):186-205. https://doi.org/10.1249/MSS.0b013e3182 79a10a.

49. Edwards JP, Walsh NP, Diment PC, et al. Anxiety and perceived psychological stress play an important role in the immune response after exercise. Exerc Immunol Rev. 2018;24:26-34.

50. Fondell E, Lagerros YT, Sundberg CJ, et al. Physical activity, stress, and self-reported upper respiratory tract infection. Med Sci Sports Exerc. 2011;43(2):272-9. https://doi.org/10.1249/ MSS.0b013e3181edf108.

51. Calder PC. Feeding the immune system. Proc Nutr Soc. 2013;72(3):299-309. https://doi.org/10.1017/S00296651130012 86.

52. Woodward B. Protein, calories, and immune defenses. Nutr Rev. 1998;56(1 Pt 2):S84-92.

53. Pelletier DL, Frongillo EA Jr, Schroeder DG, et al. The effects of malnutrition on child mortality in developing countries. Bull World Health Organ. 1995;73(4):443-8.

54. Hemilä H. Vitamin C and infections. Nutrients. 2017. https://doi. org/10.3390/nu9040339.
55. He CS, Aw Yong XH, Walsh NP, et al. Is there an optimal vitamin D status for immunity in athletes and military personnel? Exerc Immunol Rev. 2016;22:42-64.

56. Colbey C, Cox AJ, Pyne DB, et al. Upper respiratory symptoms, gut health and mucosal immunity in athletes. Sports Med. 2018;48(Suppl. 1):65-77. https://doi.org/10.1007/s4027 9-017-0846-4.

57. Hemilä H. Zinc lozenges and the common cold: a meta-analysis comparing zinc acetate and zinc gluconate, and the role of zinc dosage. JRSM Open. 2017;8(5):2054270417694291. https://doi. org/10.1177/2054270417694291.

58. Mountjoy M, Sundgot-Borgen JK, Burke LM, et al. IOC consensus statement on Relative Energy Deficiency in Sport (RED-S): 2018 update. Br J Sports Med. 2018;52(11):687-97. https://doi. org/10.1136/bjsports-2018-099193.

59. De Souza MJ, Williams NI, Nattiv A, et al. Misunderstanding the female athlete triad: refuting the IOC consensus statement on Relative Energy Deficiency in Sport (RED-S). Br J Sports Med. 2014;48(20):1461-5. https://doi.org/10.1136/bjsports-2014093958.

60. Nova E, Samartin S, Gomez S, et al. The adaptive response of the immune system to the particular malnutrition of eating disorders. Eur J Clin Nutr. 2002;56(Suppl. 3):S34-7. https://doi. org/10.1038/sj.ejcn.1601.

61. Marcos A. The immune system in eating disorders: an overview. Nutrition. 1997;13(10):853-62.

62. Reas DL, Ro O. Investigating the DSM-5 severity specifiers based on thinness for adults with anorexia nervosa. Int $\mathrm{J}$ Eat Disord. 2017;50(8):990-4. https://doi.org/10.1002/eat.22729.

63. Marcos A. Eating disorders: a situation of malnutrition with peculiar changes in the immune system. Eur J Clin Nutr. 2000;54(Suppl. 1):S61-4.

64. Hart BL. Behavioral adaptations to pathogens and parasites: five strategies. Neurosci Biobehav Rev. 1990;14(3):273-94.

65. Wang A, Huen SC, Luan HH, et al. Opposing effects of fasting metabolism on tissue tolerance in bacterial and viral inflammation. Cell. 2016;166(6):1512e12-1525e12. https://doi. org/10.1016/j.cell.2016.07.026.

66. Pertschuk MJ, Crosby LO, Barot L, et al. Immunocompetency in anorexia nervosa. Am J Clin Nutr. 1982;35(5):968-72. https ://doi.org/10.1093/ajen/35.5.968.

67. Victora CG, Kirkwood BR, Ashworth A, et al. Potential interventions for the prevention of childhood pneumonia in developing countries: Improving nutrition. Am J Clin Nutr. 1999;70(3):30920. https://doi.org/10.1093/ajcn/70.3.309.

68. Schaible UE, Kaufmann SH. Malnutrition and infection: complex mechanisms and global impacts. PLoS Med. 2007;4(5):e115. https://doi.org/10.1371/journal.pmed.0040115.

69. Nova E, Varela P, Lopez-Vidriero I, et al. A one-year follow-up study in anorexia nervosa: dietary pattern and anthropometrical evolution. Eur J Clin Nutr. 2001;55(7):547-54. https://doi. org/10.1038/sj.ejen.1601181.

70. Field CJ, Gougeon R, Marliss EB. Changes in circulating leukocytes and mitogen responses during very-low-energy all-protein reducing diets. Am J Clin Nutr. 1991;54(1):123-9. https://doi. org/10.1093/ajen/54.1.123.

71. Taylor AK, Cao W, Vora KP, et al. Protein energy malnutrition decreases immunity and increases susceptibility to influenza infection in mice. J Infect Dis. 2013;207(3):501-10. https://doi. org/10.1093/infdis/jis527.

72. Phillips SM. Dietary protein requirements and adaptive advantages in athletes. Br J Nutr. 2012;108(Suppl. 2):S158-67. https ://doi.org/10.1017/S0007114512002516.

73. Heikura IA, Uusitalo ALT, Stellingwerff T, et al. Low energy availability is difficult to assess but outcomes have large impact on bone injury rates in elite distance athletes. Int J Sport Nutr 
Exerc Metab. 2018;28(4):403-11. https://doi.org/10.1123/ijsne m.2017-0313.

74. Mountjoy M, Sundgot-Borgen J, Burke L, et al. The IOC consensus statement: beyond the female athlete triad-Relative Energy Deficiency in Sport (RED-S). Br J Sports Med. 2014;48(7):4917. https://doi.org/10.1136/bjsports-2014-093502.

75. Ackerman KE, Holtzman B, Cooper KM, et al. Low energy availability surrogates correlate with health and performance consequences of Relative Energy Deficiency in Sport. Br J Sports Med. 2019;53(10):628-33. https://doi.org/10.1136/bjsports2017-098958.

76. Greenberg DB. Depression, anxiety, and Epstein-Barr virus infection. Ann Intern Med. 1986;104(3):449.

77. Mattar L, Thiebaud MR, Huas C, et al. Depression, anxiety and obsessive-compulsive symptoms in relation to nutritional status and outcome in severe anorexia nervosa. Psychiatry Res. 2012;200(2-3):513-7. https://doi.org/10.1016/j.psych res.2012.04.032.

78. Guarda AS, Schreyer CC, Boersma GJ, et al. Anorexia nervosa as a motivated behavior: relevance of anxiety, stress, fear and learning. Physiol Behav. 2015;152(Pt B):466-72. https://doi. org/10.1016/j.physbeh.2015.04.007.

79. Meydani SN, Das SK, Pieper CF, et al. Long-term moderate calorie restriction inhibits inflammation without impairing cellmediated immunity: a randomized controlled trial in non-obese humans. Aging (Albany NY). 2016;8(7):1416-31. https://doi. org/10.18632/aging.100994.

80. Fontana L, Partridge L, Longo VD. Extending healthy life span: from yeast to humans. Science. 2010;328(5976):321-6. https:// doi.org/10.1126/science.1172539.

81. Most J, Tosti V, Redman LM, et al. Calorie restriction in humans: an update. Ageing Res Rev. 2017;39:36-45. https:// doi.org/10.1016/j.arr.2016.08.005.

82. Oliver SJ, Laing SJ, Wilson S, et al. Salivary immunoglobulin a response at rest and after exercise following a $48 \mathrm{~h}$ period of fluid and/or energy restriction. Br J Nutr. 2007;97(6):1109-16. https://doi.org/10.1017/S0007114507682919.

83. Laing SJ, Oliver SJ, Wilson S, et al. Neutrophil-degranulation and lymphocyte-subset response after $48 \mathrm{hr}$ of fluid and/or energy restriction. Int J Sport Nutr Exerc Metab. 2008;18(5):443-56.

84. Diment BC, Fortes MB, Greeves JP, et al. Effect of daily mixed nutritional supplementation on immune indices in soldiers undertaking an 8-week arduous training programme. Eur J Appl Physiol. 2012;112(4):1411-8. https://doi.org/10.1007/s0042 1-011-2096-8.

85. Elliott-Sale KJ, Tenforde AS, Parziale AL, et al. Endocrine effects of relative energy deficiency in sport. Int J Sport Nutr Exerc Metab. 2018;28(4):335-49. https://doi.org/10.1123/ijsne m.2018-0127.

86. Nakamura Y, Walker BR, Ikuta T. Systematic review and metaanalysis reveals acutely elevated plasma cortisol following fasting but not less severe calorie restriction. Stress. 2016;19(2):1517. https://doi.org/10.3109/10253890.2015.1121984.

87. Venkatraman JT, Pendergast DR. Effect of dietary intake on immune function in athletes. Sports Med. 2002;32(5):323-37. https://doi.org/10.2165/00007256-200232050-00004.

88. Dhabhar FS, McEwen BS. Enhancing versus suppressive effects of stress hormones on skin immune function. Proc Natl Acad Sci USA. 1999;96(3):1059-64.

89. Cohen S, Janicki-Deverts D, Doyle WJ, et al. Chronic stress, glucocorticoid receptor resistance, inflammation, and disease risk. Proc Natl Acad Sci USA. 2012;109(16):5995-9. https:// doi.org/10.1073/pnas.1118355109.

90. Roy BA, Kirchner JW. Evolutionary dynamics of pathogen resistance and tolerance. Evolution. 2000;54(1):51-63.
91. Ayres JS, Schneider DS. Tolerance of infections. Annu Rev Immunol. 2012;30:271-94. https://doi.org/10.1146/annurevimmunol-020711-075030.

92. Moret Y, Schmid-Hempel P. Survival for immunity: the price of immune system activation for bumblebee workers. Science. 2000;290(5494):1166-8.

93. Lazzaro BP, Rolff J. Immunology: danger, microbes, and homeostasis. Science. 2011;332(6025):43-4. https://doi.org/10.1126/ science. 1200486.

94. Schneider DS, Ayres JS. Two ways to survive infection: what resistance and tolerance can teach us about treating infectious diseases. Nat Rev Immunol. 2008;8(11):889-95. https://doi. org/10.1038/nri2432.

95. Matzinger P. The danger model: a renewed sense of self. Science. 2002;296(5566):301-5. https://doi.org/10.1126/science.1071059.

96. Prasad AS. Zinc: role in immunity, oxidative stress and chronic inflammation. Curr Opin Clin Nutr Metab Care. 2009;12(6):64652. https://doi.org/10.1097/MCO.0b013e3283312956.

97. Wu D, Lewis ED, Pae M, et al. Nutritional modulation of immune function: analysis of evidence, mechanisms, and clinical relevance. Front Immunol. 2018;9:3160. https://doi.org/10.3389/ fimmu.2018.03160.

98. Nieman DC, Bishop NC. Nutritional strategies to counter stress to the immune system in athletes, with special reference to football. J Sports Sci. 2006;24(7):763-72. https://doi. org/10.1080/02640410500482982.

99. Bishop NC, Blannin AK, Walsh NP, et al. Nutritional aspects of immunosuppression in athletes. Sports Med. 1999;28(3):151-76. https://doi.org/10.2165/00007256-199928030-00002.

100. Novick SG, Godfrey JC, Godfrey NJ, et al. How does zinc modify the common cold? Clinical observations and implications regarding mechanisms of action. Med Hypotheses. 1996;46(3):295-302.

101. Eby GA 3rd. Zinc lozenges as cure for the common cold: a review and hypothesis. Med Hypotheses. 2010;74(3):482-92. https://doi.org/10.1016/j.mehy.2009.10.017.

102. Prasad AS, Beck FW, Bao B, et al. Duration and severity of symptoms and levels of plasma interleukin-1 receptor antagonist, soluble tumor necrosis factor receptor, and adhesion molecules in patients with common cold treated with zinc acetate. J Infect Dis. 2008;197(6):795-802. https://doi.org/10.1086/528803.

103. Micheletti A, Rossi R, Rufini S. Zinc status in athletes: relation to diet and exercise. Sports Med. 2001;31(8):577-82. https://doi. org/10.2165/00007256-200131080-00002.

104. Hemilä H, Petrus EJ, Fitzgerald JT, et al. Zinc acetate lozenges for treating the common cold: an individual patient data metaanalysis. Br J Clin Pharmacol. 2016;82(5):1393-8. https://doi. org/10.1111/bcp.13057.

105. Castell LM, Poortmans JR, Newsholme EA. Does glutamine have a role in reducing infections in athletes? Eur J Appl Physiol. 1996;73(5):488-90.

106. Walsh NP, Blannin AK, Robson PJ, et al. Glutamine, exercise and immune function: links and possible mechanisms. Sports Med. 1998;26(3):177-91.

107. Henson DA, Nieman DC, Parker JC, et al. Carbohydrate supplementation and the lymphocyte proliferative response to long endurance running. Int J Sports Med. 1998;19(8):574-80. https ://doi.org/10.1055/s-2007-971962.

108. Nieman DC, Henson DA, Fagoaga OR, et al. Change in salivary $\operatorname{IgA}$ following a competitive marathon race. Int J Sports Med. 2002;23(1):69-75. https://doi. org/10.1055/s-2002-19375.

109. Lancaster GI, Khan Q, Drysdale PT, et al. Effect of prolonged exercise and carbohydrate ingestion on type 1 and type $2 \mathrm{~T}$ lymphocyte distribution and intracellular cytokine production 
in humans. J Appl Physiol. (1985). 2005;98(2):565-71. https ://doi.org/10.1152/japplphysiol.00754.2004.

110. Bishop NC, Walker GJ, Gleeson M, et al. Human T lymphocyte migration towards the supernatants of human rhinovirus infected airway epithelial cells: influence of exercise and carbohydrate intake. Exerc Immunol Rev. 2009;15:127-44.

111. Brinkworth GD, Buckley JD. Concentrated bovine colostrum protein supplementation reduces the incidence of self-reported symptoms of upper respiratory tract infection in adult males. Eur J Nutr. 2003;42(4):228-32. https://doi.org/10.1007/s0039 4-003-0410-x.

112. Davison G, Diment BC. Bovine colostrum supplementation attenuates the decrease of salivary lysozyme and enhances the recovery of neutrophil function after prolonged exercise. $\mathrm{Br}$ J Nutr. 2010;103(10):1425-32. https://doi.org/10.1017/S0007 114509993503.

113. Jones AW, March DS, Thatcher R, et al. The effects of bovine colostrum supplementation on in vivo immunity following prolonged exercise: a randomised controlled trial. Eur J Nutr. 2019;58(1):335-44. https://doi.org/10.1007/s0039 4-017-1597-6.

114. Williams NC, Killer SC, Svendsen IS, et al. Immune nutrition and exercise: narrative review and practical recommendations. Eur J Sport Sci. 2019;19(1):49-61. https://doi.org/10.1080/17461 391.2018.1490458.

115. Nieman DC, Henson DA, McMahon M, et al. Beta-glucan, immune function, and upper respiratory tract infections in athletes. Med Sci Sport Exer. 2008;40(8):1463-71. https://doi. org/10.1249/MSS.0b013e31817057c2.

116. Volman JJ, Ramakers JD, Plat J. Dietary modulation of immune function by beta-glucans. Physiol Behav. 2008;94(2):276-84. https://doi.org/10.1016/j.physbeh.2007.11.045.

117. McFarlin BK, Carpenter KC, Davidson T, et al. Baker's yeast beta glucan supplementation increases salivary iga and decreases cold/flu symptomatic days after intense exercise. J Diet Suppl. 2013;10(3):171-83. https://doi.org/10.3109/19390 211.2013.820248.

118. Karsch-Volk M, Barrett B, Linde K. Echinacea for preventing and treating the common cold. JAMA. 2015;313(6):618-9. https:// doi.org/10.1001/jama.2014.17145.

119. Walker GJ, Finlay O, Griffiths H, et al. Immunoendocrine response to cycling following ingestion of caffeine and carbohydrate. Med Sci Sport Exer. 2007;39(9):1554-60. https://doi. org/10.1249/mss.0b013e3180a74228.

120. Dulson DK, Bishop NC. Effect of a high and low dose of caffeine on human lymphocyte activation in response to antigen stimulation. Appl Physiol Nutr Metab. 2016;41(2):224-7. https://doi. org/10.1139/apnm-2015-0456.

121. Maughan RJ, Burke LM, Dvorak J, et al. IOC consensus statement: dietary supplements and the high-performance athlete. $\mathrm{Br}$ J Sports Med. 2018;52(7):439-55. https://doi.org/10.1136/bjspo rts-2018-099027.

122. Gleeson M, Bishop NC, Oliveira M, et al. Daily probiotic's (Lactobacillus casei shirota) reduction of infection incidence in athletes. Int J Sport Nutr Exerc Metab. 2011;21(1):55-64.

123. McFarland LV, Goh S. Are probiotics and prebiotics effective in the prevention of travellers' diarrhea: a systematic review and meta-analysis. Travel Med Infect Dis. 2019;27:11-9. https ://doi.org/10.1016/j.tmaid.2018.09.007.

124. Hao Q, Dong BR, Wu T. Probiotics for preventing acute upper respiratory tract infections. Cochrane Database Syst Rev. 2015. https://doi.org/10.1002/14651858.cd006895.pub3.

125. Hemilä $\mathrm{H}$, Chalker E. Vitamin $\mathrm{C}$ for preventing and treating the common cold. Cochrane Database Syst Rev. 2013. https:// doi.org/10.1002/14651858.cd000980.pub4.
126. Martineau AR, Jolliffe DA, Hooper RL, et al. Vitamin D supplementation to prevent acute respiratory tract infections: systematic review and meta-analysis of individual participant data. BMJ. 2017;356:i6583. https://doi.org/10.1136/bmj.i6583.

127. Carswell AT, Oliver SJ, Wentz LM, et al. Influence of vitamin D supplementation by sunlight or oral D3 on exercise performance. Med Sci Sports Exerc. 2018;50(12):2555-64. https:// doi.org/10.1249/MSS.0000000000001721.

128. Ross AC, Manson JE, Abrams SA, et al. The 2011 report on dietary reference intakes for calcium and vitamin $\mathrm{D}$ from the Institute of Medicine: what clinicians need to know. J Clin Endocrinol Metab. 2011;96(1):53-8. https://doi.org/10.1210/ jc. 2010-2704.

129. Nieman DC, Henson DA, Gross SJ, et al. Quercetin reduces illness but not immune perturbations after intensive exercise. Med Sci Sport Exer. 2007;39(9):1561-9. https://doi.org/10.1249/ mss.0b013e318076b566.

130. Gleeson M. Immunological aspects of sport nutrition. Immunol Cell Biol. 2016;94:117-23. https://doi.org/10.1038/icb.2015.109.

131. McAnulty SR, Nieman DC, Fox-Rabinovich M, et al. Effect of n-3 fatty acids and antioxidants on oxidative stress after exercise. Med Sci Sports Exerc. 2010;42(9):1704-11. https://doi. org/10.1249/MSS.0b013e3181d85bd1.

132. Mickleborough TD. Omega-3 polyunsaturated fatty acids in physical performance optimization. Int J Sport Nutr Exerc Metab. 2013;23(1):83-96.

133. Jakeman JR, Lambrick DM, Wooley B, et al. Effect of an acute dose of omega-3 fish oil following exercise-induced muscle damage. Eur J Appl Physiol. 2017;117(3):575-82. https://doi. org/10.1007/s00421-017-3543-y.

134. Meydani SN, Meydani M, Blumberg JB, et al. Vitamin E supplementation and in vivo immune response in healthy elderly subjects: a randomized controlled trial. JAMA. 1997;277(17):1380-6.

135. Hemilä H, Virtamo J, Albanes D, et al. Physical activity and the common cold in men administered vitamin $\mathrm{E}$ and beta-carotene. Med Sci Sport Exer. 2003;35(11):1815-20. https://doi. org/10.1249/01.MSS.0000093616.60899.92.

136. Meydani SN, Han SN, Hamer DH. Vitamin E and respiratory infection in the elderly. Ann N Y Acad Sci. 2004;1031:214-22. https://doi.org/10.1196/annals.1331.021.

137. Hill C, Guarner F, Reid G, et al. Expert consensus document: the international scientific association for probiotics and prebiotics consensus statement on the scope and appropriate use of the term probiotic. Nat Rev Gastroenterol Hepatol. 2014;11(8):506-14. https://doi.org/10.1038/nrgastro.2014.66.

138. Thomas CM, Versalovic J. Probiotics-host communication: modulation of signaling pathways in the intestine. Gut Microbes. 2010;1(3):148-63.

139. Pyne DB, West NP, Cox AJ, et al. Probiotics supplementation for athletes: clinical and physiological effects. Eur J Sport Sci. 2015;15(1):63-72. https://doi.org/10.1080/17461 391.2014 .971879$.

140. Cox AJ, Pyne DB, Saunders PU, et al. Oral administration of the probiotic lactobacillus fermentum vri-003 and mucosal immunity in endurance athletes. Br J Sports Med. 2010;44(4):222-6. https ://doi.org/10.1136/bjsm.2007.044628.

141. Shing CM, Peake JM, Lim CL, et al. Effects of probiotics supplementation on gastrointestinal permeability, inflammation and exercise performance in the heat. Eur J Appl Physiol. 2014;114(1):93-103. https://doi.org/10.1007/s0042 1-013-2748-y.

142. Kekkonen RA, Vasankari TJ, Vuorimaa T, et al. The effect of probiotics on respiratory infections and gastrointestinal symptoms during training in marathon runners. Int J Sport Nutr Exerc Metab. 2007;17(4):352-63. 
143. Hume R, Weyers E. Changes in leucocyte ascorbic acid during the common cold. Scott Med J. 1973;18(1):3-7. https://doi. org/10.1177/003693307301800102.

144. Powers SK, Jackson MJ. Exercise-induced oxidative stress: cellular mechanisms and impact on muscle force production. Physiol Rev. 2008;88(4):1243-76. https://doi.org/10.1152/physrev.00031 .2007.

145. Peters EM, Goetzsche JM, Grobbelaar B, et al. Vitamin C supplementation reduces the incidence of postrace symptoms of upperrespiratory-tract infection in ultramarathon runners. Am J Clin Nutr. 1993;57(2):170-4. https://doi.org/10.1093/ajen/57.2.170.

146. Hemilä $\mathrm{H}$. Vitamin $\mathrm{C}$ and exercise-induced bronchoconstriction in athletes. J Allergy Clin Immunol. 2009;123(1):274-5. https:// doi.org/10.1016/j.jaci.2008.10.004.

147. Anderson SD, Kippelen P. Airway injury as a mechanism for exercise-induced bronchoconstriction in elite athletes. J Allergy Clin Immunol. 2008;122(2):225-35. https://doi.org/10.1016/j. jaci.2008.05.001 (quiz 36-7).

148. Anderson TW, Suranyi G, Beaton GH. The effect on winter illness of large doses of vitamin C. Can Med Assoc J. 1974;111(1):31-6.

149. Karlowski TR, Chalmers TC, Frenkel LD, et al. Ascorbic acid for the common cold: a prophylactic and therapeutic trial. JAMA. 1975;231(10):1038-42.

150. Gomez-Cabrera MC, Domenech E, Romagnoli M, et al. Oral administration of vitamin $\mathrm{C}$ decreases muscle mitochondrial biogenesis and hampers training-induced adaptations in endurance performance. Am J Clin Nutr. 2008;87(1):142-9. https:// doi.org/10.1093/ajen/87.1.142.

151. Roberts LA, Beattie K, Close GL, et al. Vitamin C consumption does not impair training-induced improvements in exercise performance. Int J Sports Physiol Perform. 2011;6(1):58-69.

152. Paulsen G, Cumming KT, Holden G, et al. Vitamin C and E supplementation hampers cellular adaptation to endurance training in humans: a double-blind, randomised, controlled trial. J Physiol. 2014;592(8):1887-901. https://doi.org/10.1113/jphys iol.2013.267419.

153. Yfanti C, Akerstrom T, Nielsen S, et al. Antioxidant supplementation does not alter endurance training adaptation. Med Sci Sports Exerc. 2010;42(7):1388-95. https://doi.org/10.1249/ MSS.0b013e3181cd76be.
154. Cannell JJ, Vieth R, Umhau JC, et al. Epidemic influenza and vitamin D. Epidemiol Infect. 2006;134(6):1129-40. https://doi. org/10.1017/S0950268806007175.

155. Berry DJ, Hesketh K, Power C, et al. Vitamin D status has a linear association with seasonal infections and lung function in British adults. Br J Nutr. 2011;106(9):1433-40. https://doi. org/10.1017/S0007114511001991.

156. Close GL, Russell J, Cobley JN, et al. Assessment of vitamin $\mathrm{D}$ concentration in non-supplemented professional athletes and healthy adults during the winter months in the UK: implications for skeletal muscle function. J Sports Sci. 2013;31(4):344-53. https://doi.org/10.1080/02640414.2012.733822.

157. Laaksi IT, Ruohola JP, Ylikomi TJ, et al. Vitamin D fortification as public health policy: Significant improvement in vitamin D status in young Finnish men. Eur J Clin Nutr. 2006;60(8):1035-8. https://doi.org/10.1038/sj.ejcn.1602414.

158. Ginde AA, Mansbach JM, Camargo CA Jr. Association between serum 25-hydroxyvitamin D level and upper respiratory tract infection in the third national health and nutrition examination survey. Arch Intern Med. 2009;169(4):384-90. https://doi. org/10.1001/archinternmed.2008.560.

159. Laaksi I, Ruohola JP, Tuohimaa P, et al. An association of serum vitamin $\mathrm{D}$ concentrations $<40 \mathrm{nmol} / \mathrm{l}$ with acute respiratory tract infection in young Finnish men. Am J Clin Nutr. 2007;86(3):714-7. https://doi.org/10.1093/ajen/86.3.714.

160. He CS, Handzlik M, Fraser WD, et al. Influence of vitamin D status on respiratory infection incidence and immune function during 4 months of winter training in endurance sport athletes. Exerc Immunol Rev. 2013;19:86-101.

161. Rhodes LE, Webb AR, Fraser HI, et al. Recommended summer sunlight exposure levels can produce sufficient ( $>$ or $=20 \mathrm{ng} \mathrm{ml}(-1)$ ) but not the proposed optimal ( $>$ or $=32 \mathrm{ng} \mathrm{ml}(-1)) 25(\mathrm{oh}) \mathrm{d}$ levels at UK latitudes. J Invest Dermatol. 2010;130(5):1411-8. https://doi.org/10.1038/ jid.2009.417.

162. Webb AR, Kift R, Berry JL, et al. The vitamin D debate: translating controlled experiments into reality for human sun exposure times. Photochem Photobiol. 2011;87(3):741-5. https://doi.org/ 10.1111/j.1751-1097.2011.00898.x. 